\title{
Practical aspects of the use of FMEA tool in clinical laboratory risk management
}

\author{
Aspectos práticos da utilização da ferramenta FMEA \\ na gestão de riscos do laboratório clínico
}

Maria Elizabete Mendes ${ }^{1}$; Pérsio de Almeida Rezende Ebner²; Paschoalina Romano3;

Maurílio Pacheco Neto ${ }^{4}$ Alexandre Sant'anna ${ }^{5}$ N Nairo Massakazu Sumita ${ }^{6}$

\begin{abstract}
Introduction: This paper presents the failure modes and effects analysis (FMEA) tool in a clinical laboratory through the introduction of new technology for blood gas and serum ionized calcium in multi-parameter analyzers such as Point of Care Testing (POCT). Objective: To present FMEA as a tool for risk managing and improvement with the introduction of new technologies in a public laboratory. Methods: The change of multiparameter gas analyzer type POCT was defined and described as a process. Subsequently, the criteria were presented to the risk assessment and its quantification. We studied the failure modes that might occur in this process. We established three action plans involving improvements to be made in the technological change. FMEA was applied in two stages: at the beginning of the project and after the implementation of the proposed measures. Results: The first plan involved administrative measures related to the bidding process; the second preventive action involved the possibility of which supplier would win the bid by studying the efficiency of the analyzer and its impact on productivity; the third set of actions was directed to improvements in the relationship with the clinical staff in order to minimize occasional complaints. The last actions referred to employing new employees to meet the growing demand. Conclusion: FMEA proved to be a reliable tool for performance improvement, which proactively identifies, prioritizes and mitigates patient risks.
\end{abstract}

Key words: clinical laboratory; risk management; risk analysis; FMEA; patient safety; blood gas analysis.

\section{INTRODUCTION}

Suppliers and service providers are involved with patient safety in the pursuit of reducing the risk of damages, injuries, infections, side effects or other hazards related to health care. All health professionals should act preventively with the aim to minimize the flaws in the entire patient care flow, thus enabling a safer health system $^{(19)}$.
Laboratory tests support about 70\% of medical decisions ${ }^{(24)}$. The turn around time (TAT) and the accuracy of results are critical to the diagnostic reliability and treatment effectiveness. Although the rate of laboratory error is low when compared to the billions of examinations performed daily worldwide, their implications for public health and patient safety are relevant.

The regulations from the Brazilian Association of Technical Standards/Technical Committee (ABNT NM-ISO/TC)

First submission on 23/10/12; last submission on 12/12/12; accepted for publication on 19/12/12; published on 20/06/13

1. Clinical Pathologist by Faculdade de Medicina da Universidade de São Paulo (FMUSP); chief at the Technical Section of Blood Biochemistry from the Central Laboratory Division of FMUSP Clinical Hospital/Laboratory of Medical Investigation (DLC-HCFMUSP/LIM-03).

2. Chief biologist at the Quality Control Department of DLC-HCFMUSP/LIM-03.

3. Master in Health Sciences by FMUSP Program of Experimental Physiopathology; biologist responsible for the DLC-HCFMUSP/LIM-03.

4. Master in Health Science by FMUSP Experimental Physiopathology Program; pharmacist at the Technical Section of Blood Biochemistry from DLC-HCFMUSP/LIM-03.

5. Master in Biotechnology, Nanotechnology and Molecular Biology by Academia de Ciências do Vaticano; laboratory technician at the Technical Section of Blood Biochemistry from DLC-HCFMUSP/LIM-03.

6. Clinical Pathologist by FMUSP; director of Clinical Biochemistry Service from DLC-HCFMUSP/LIM-03. 
22367:2009 $9^{(1)}$ define risk as the potential to cause harm, either due to physical agent, chemical product, infectious material, functioning or non-functioning equipment, environmental action or human behavior ${ }^{(1)}$.

A risk is defined as an event that produces negative effect, directly or indirectly (injury, damage or loss), on the quality of care, which may threaten people's safety and/or lives, affect the image of the institution and generate additional costs. Risk management in the clinical laboratory corresponds to a set of actions to recognize or identify risks, assess the probability of something happening in case of hazard and evaluate the severity of their consequences.

Laboratory medicine service managers are aware that to err is human ${ }^{(19)}$, therefore they establish preventive measures to minimize the possibility of errors. Each early detection or prevention of failure is another step toward ensuring the quality of results and improvement in patient care, which approximates the laboratory operation to zero error ${ }^{(9)}$. Successful programs for laboratory quality management keep the focus on the processes, the provision of required tools and employee accountability in order to ensure continuous work improvement.

Risk management has been disseminated in Laboratory Medicine only for the last years, although it has been applied in healthcare since the 80 s. That was partly due to constant inspections during the cycle of laboratory examination, rework, removal of any defects and adjustment after the identification of possible causes of flaws or errors.

One of the instruments used in risk management is the analysis of failure modes and effects analysis (FMEA). Companies that use it properly not only save resources but also maintain a high level of customer satisfaction ${ }^{(26)}$. In November 1949, a military standard procedure was developed by the National Aeronautics and Space Administration (NASA), which was denominated Military Procedure MIL-P-1629 Procedures for Performing a Failure Mode, Effects and Criticality Analysis ${ }^{(20)}$.The goal was to standardize a method for evaluating system and equipment reliability in order to determine the effects of their failures on the success of military missions as well as personnel and equipment safety

FMEA tool is useful and applicable in the following situations:

- increasing customer satisfaction;

- decision making on the introduction of new product or process;

- drawing up plans to control newly established processes;

- processes already in place when new improvement goals are established to ensure more reliability;
- study on large modifications of existing products or processes;

- analysis of flaws in existing processes to improve quality;

- supplier development;

- optimization of maintenance plans for equipment and infrastructure;

- as a tool for organizational learning.

\section{Implementation barriers $^{(5)}$}

There is a reluctance in adopting a culture of prevention when FMEA is employed in the clinical laboratory. This is because it requires an experienced and multidisciplinary work team. The required information is not always easily available. There are immutable processes. Interfaces go beyond the laboratory limits, involving other hospital areas. There are other tools and well-established effective systems in use. There is also some staff resistance to changes.

\section{Implementation progress}

Like any organizational innovation, FMEA should be thoroughly understood prior to being introduced in laboratory practice. There are five stages in its introduction ${ }^{(11)}$ :

phase 1 - initial contact with the method, period in which there is still poor understanding of the instrument and its applications;

phase 2 - FMEA learning step, in which its value is acknowledged;

phase 3 - correct construction of FMEA, with improvements in its preparation without application of action plans;

phase 4 - the managers realize that preventive actions identified by FMEA aid to change the systems and processes, hence improving work and its products therein;

phase 5 - the processes have been adapted. FMEA becomes the query object before any changes or in face of inadequacy.

\section{FMEA and patient safety}

Since 2001 the Joint Commission on Accreditation of Health Care Organization (JCAHO) $)^{(12)}$ has required the use of this instrument from emergency hospitals, which proves its validity to reduce medical errors ${ }^{(11)}$. Accordingly, new skills are required from the leaderships. 
In 2002, the Veterans Affairs National Center for Patient Safety developed an alternative method specifically for health care: the health care failure mode and effect analysis (FMECA-H) ${ }^{(4)}$. This new concept modifies and expands the use of this instrument, adding a critical component, the flow diagram, which is both the damage assessment matrix and the decision tree to identify and assess potential vulnerabilities.

In 2004, Capunzo et al. ${ }^{(10)}$ applied this technique in some analytes from clinical laboratories - glucose, cholesterol and bilirubin - correcting unconformities observed in storage, contamination of reagents and calibrators.

Woodhouse ${ }^{(30)}$, in their study on FMEA in a hemotherapy service, noted that for each of the eleven identified processes, potential failure modes were developed and solutions were deployed. This reduced the possibility of error occurrence and increased the probability of detection.

ABNT NM-ISO/TC 22367:2009(1) regulation prescribes that FMEA should be used to reduce errors and improve patient safety in laboratory medicine.

\section{FMEA in practice (6,9, $14,15,30)^{2}$}

In general, the application in the clinical laboratory may be outlined by defining the process to be studied, establishing a specific work team, compiling, organizing and analyzing a set of information about the probable failures. Subsequently, the risks for each type of failure and their prioritization levels are assessed. In addition, strategies are developed and the planning of preventive actions is made by sharing tasks among staff members and providing the required resources. The adaptations and/or improvements in processes are performed as planned and once they are accomplished, the effectiveness of the actions is verified, reassessing the risk level, hence establishing a cycle of improvements.

\section{OBJECTIVE}

This article aims to present FMEA as a tool for risk management and public laboratory improvement. The chances of failure were analyzed to plan the introduction of new technologies, with production increase, changes in workflow and development of patient safety.

\section{METHODS}

The study was conducted at the Department of Clinical Biochemistry from the Central Laboratory Division of FMUSP
Clinical Hospital. An experienced and multidisciplinary work team was made up. Furthermore, we employed a PDSA cycle (PLAN - DO - STUDY - ACT) in this task.

The criteria for risk assessment were defined by the nature and types of failures, failure modes, failure effects, failure probability, risk level, and combinations thereof.

Failure modes or ways in which there may be failure were observed in the components of the process: failure to execute and close the transaction on time, loss of revenue and reduced operational capacity.

The effect analysis focused on the consequences of the identified failures. The sources of risk, impact areas, events and their causes, potential consequences and possible missed opportunities were identified in a comprehensive manner.

This risk analysis included all activities that constituted the process, each type of failure that could affect the patient, its severity, the probability of each failure occurrence, the most critical effects of each failure, the main potential causes of these effects and their consequences (positive and negative). The introduction of controls or not and its effectiveness were also contemplated.

Quantification was aimed at making decisions, thus prioritizing its implementation (Table 1).

\section{Risk priority score (RPS)}

The score was obtained by multiplying three factors: effect severity, occurrence and detection. The limit of this index, from which preventive actions would be taken to prevent risk, minimize it or extinguish it, was forty (40) points.

The process defined for the application of this tool was the replacement of the technology that involves the assessment of arterial blood gases (arterial and venous) and serum ionized calcium (Cai), performed in multiparameter analyzers. We assessed productivity and efficiency (total attendance time for these routines) of these analytes, encompassing the period of 2010 to 2011. Furthermore, we investigated the average lifetime of analyzers, which was seven years. The process performance was evaluated in the pre and post implementation of the planned actions based on FMEA worksheets and RPS, which helped in prioritizing actions.

We used Microsoft Office program - Microsoft Excel 2010 for the preparation of spreadsheets and calculations. 
TABLE 1 - Risk quantification

\begin{tabular}{|c|c|c|}
\hline \multicolumn{3}{|c|}{ Effect severity (S) } \\
\hline Score & \multicolumn{2}{|c|}{ Severity description } \\
\hline 4 & \multicolumn{2}{|c|}{ Catastrophic } \\
\hline 3 & \multicolumn{2}{|c|}{ Critical } \\
\hline 2 & \multicolumn{2}{|c|}{ Moderate } \\
\hline 1 & \multicolumn{2}{|c|}{ Minor } \\
\hline \multicolumn{3}{|c|}{ Failure occurrence (0) } \\
\hline Score & Occurrence characteristics & Description of occurrence probability \\
\hline 5 & Continuous & Daily \\
\hline 4 & Frequent & Weekly \\
\hline 3 & Occasional & Monthly \\
\hline 2 & Uncommon & It may occur within 1 to 6 weeks \\
\hline 1 & Remote & It may occur annually \\
\hline \multicolumn{3}{|c|}{ Failure detection (D) } \\
\hline Score & \multicolumn{2}{|c|}{ Description of detection mechanisms } \\
\hline 4 & \multicolumn{2}{|c|}{ The existing mechanisms will not identify } \\
\hline 3 & \multicolumn{2}{|c|}{ Controls are partial } \\
\hline 2 & \multicolumn{2}{|c|}{ Current controls would detect immediate failures, but they are not fail-safe } \\
\hline 1 & \multicolumn{2}{|c|}{ Certain of detecting the failure before affecting the patient } \\
\hline
\end{tabular}

\section{RESULTS}

The Figure describes the proposed map of technological innovation process. The work team was prepared for the use of FMEA tool through a 24-hour training. Thus, an operational routine was elaborated containing the walkthrough for this application.
There was an increasing average productivity of arterial blood gases and Cai during the study period, with a productivity of 27 and 29 test/hour/person assessed in 2010 and 2011, respectively.

In the Table 2 where we observe 48 RPS points, the first action plan aimed at a set of administrative approaches related to the bidding process and its monitoring, with the intent to maximize efficiency. Measures were adopted by the technical laboratory

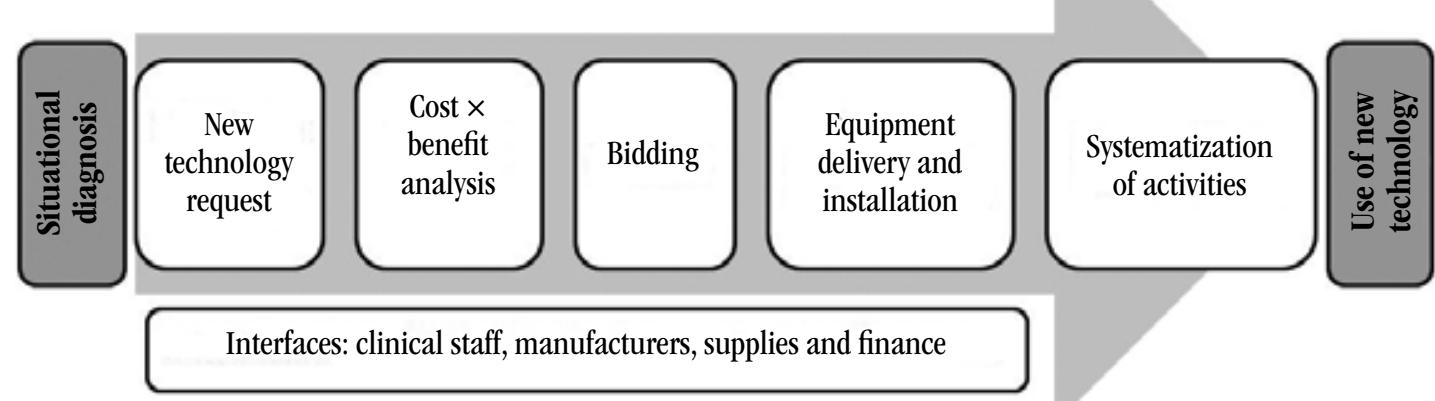

FIGURE - Flowchart of the proposed technological innovation process 
TABLE 2 - Initial FMEA analysis

\begin{tabular}{|c|c|c|c|c|c|c|c|c|c|c|}
\hline Phase & Failure mode & Potential effect & Severity & Potential cause & $\begin{array}{l}\text { Prevention } \\
\text { controls }\end{array}$ & Occurrence & $\begin{array}{l}\text { Detection } \\
\text { controls }\end{array}$ & Detection & RPN & Action \\
\hline 1 & Delay in documentation & $\begin{array}{l}\text { Equipment } \\
\text { delivery delay }\end{array}$ & 4 & $\begin{array}{l}\text { Failure in program } \\
\text { monitoring }\end{array}$ & $\begin{array}{l}\text { Controls are } \\
\text { less effective }\end{array}$ & 4 & $\begin{array}{c}\text { Partial } \\
\text { detection }\end{array}$ & 3 & 48 & 1 \\
\hline 2 & $\begin{array}{l}\text { Appeal from bidding } \\
\text { participants }\end{array}$ & $\begin{array}{l}\text { Equipment } \\
\text { delivery delay }\end{array}$ & 4 & $\begin{array}{l}\text { Failure in program } \\
\text { monitoring }\end{array}$ & $\begin{array}{l}\text { Controls are } \\
\text { less effective }\end{array}$ & 4 & $\begin{array}{c}\text { Partial } \\
\text { detection }\end{array}$ & 3 & 48 & 1 \\
\hline 3 & $\begin{array}{l}\text { Estimate was not } \\
\text { approved }\end{array}$ & $\begin{array}{l}\text { Equipment } \\
\text { delivery delay }\end{array}$ & 4 & $\begin{array}{l}\text { Failure in program } \\
\text { monitoring }\end{array}$ & $\begin{array}{l}\text { Controls are } \\
\text { less effective }\end{array}$ & 4 & $\begin{array}{c}\text { Partial } \\
\text { detection }\end{array}$ & 3 & 48 & 1 \\
\hline 4 & $\begin{array}{l}\text { Increase in time of } \\
\text { equipment operation }\end{array}$ & Increase in TST & 4 & Device specification & Frequent & 5 & $\begin{array}{l}\text { Detection in } \\
75 \% \text { of the cases }\end{array}$ & 2 & 40 & 2 \\
\hline 5 & $\begin{array}{l}\text { Increase in time of } \\
\text { equipment operation }\end{array}$ & $\begin{array}{l}\text { Insufficient } \\
\text { equipment }\end{array}$ & 4 & Device specification & Frequent & 5 & $\begin{array}{l}\text { Detection in } \\
75 \% \text { of the cases }\end{array}$ & 2 & 40 & 2 \\
\hline 6 & $\begin{array}{l}\text { Increase in time of } \\
\text { equipment operation }\end{array}$ & $\begin{array}{l}\text { Clients' } \\
\text { complaint }\end{array}$ & 4 & Device specification & Frequent & 5 & $\begin{array}{c}\text { Partial } \\
\text { detection }\end{array}$ & 3 & 60 & 3 \\
\hline 7 & $\begin{array}{l}\text { Increase in time of } \\
\text { equipment operation }\end{array}$ & Insufficient staff & 4 & Device specification & Frequent & 5 & $\begin{array}{c}\text { Detection in } \\
75 \% \text { of the cases }\end{array}$ & 2 & 40 & 4 \\
\hline
\end{tabular}

FMEA: failure mode and effect analysis; RPN: risk priority number; TST: total service time.

staff and the hospital administrative team, reducing substantially patient risk. After performing these actions, a new evaluation showed an RPS index of four points.

The second preventive action plan was related to the possibility that a manufacturer whose equipment had a runtime three times longer than the current one for each Cai analysis could win the bid.

We analyzed operation time, workload, production trend and productivity. Moreover, we compared the number of currently installed equipment and what would be suitable. It was decided that, in this case, two additional pieces of equipment would be ordered, increasing the total from six to eight. This supplier won the bidding. The planned measures were implemented, followed by a new evaluation, whose initial RPS value dropped from 40 to12 points.

The third set of actions was addressed to the hospital staff in order to prevent the occurrence of complaints in the event described above. The group approached the hospital emergency staff. Regular monitoring meetings and installation of POCT analyzer near the hospital emergency area were proposed. It was determined that DLC would be accountable for training personnel to operate it, implementing measures to ensure the quality for these examinations, equipment maintenance and supply provision. Thus, after implementation, RPS dropped from 60 to 4 points.

The final action plan referred to the insufficient number of employees in the technical team to meet the workload increase due to new equipment and one more place of operation. Therefore, new vacancies were opened, initiating a recruitment and selection process. RPS decreased from 40 to 20 points.
The Table 3 pointed FMEA analysis after implementing the action plan.

\section{DISCUSSION}

Quality is a comprehensive and multifaceted concept whose dimensions vary in importance depending on the situation: technical competence, accessibility, effectiveness, interpersonal relationship, efficiency, continuity, safety and adequate facilities.

The systems involved in human interactions and decisions are prone to error. Therefore, it is necessary to design processes to prevent mistakes or at least make them tolerable, inasmuch as they may be contained. Laboratories fall into this category and errors may occur for several reasons. From the systems perspective, these situations must be anticipated and alternative procedures must be designed to minimize potential errors ${ }^{(13,21,23)}$. In the clinical laboratory, most errors are in the pre-analytical phase ${ }^{(7,23)}$. The criteria for assessing the risks and developing plans for preventive measures were defined in the laboratory. There is no set standard for the development and implementation of this tool in the laboratory, hindering the comparison between pairs and application of best practices.

Some of the features of the laboratory technical staff, namely the ability to think analytically as well as their familiarity with the need to establish standardization policies and strict adherence to protocols, helped in the prediction of potential errors. The results were consistent with the literature ${ }^{(2,3,28)}$. 
TABLE 3 - FMEA analysis after implementing the action plan

\begin{tabular}{|c|c|c|c|c|c|c|c|c|c|c|}
\hline Phase & Failure mode & Potential effect & Severity & Potential cause & $\begin{array}{l}\text { Prevention } \\
\text { controls }\end{array}$ & Occurrence & $\begin{array}{l}\text { Detection } \\
\text { controls }\end{array}$ & Detection & RPN & Action \\
\hline 1 & Delay in documentation & $\begin{array}{l}\text { Equipment } \\
\text { delivery delay }\end{array}$ & 4 & $\begin{array}{l}\text { Failure in program } \\
\text { monitoring }\end{array}$ & Effective control & 1 & $\begin{array}{l}\text { Efficient } \\
\text { detection }\end{array}$ & 1 & 4 & 1 \\
\hline 2 & $\begin{array}{l}\text { Appeal from bidding } \\
\text { participants }\end{array}$ & $\begin{array}{l}\text { Equipment } \\
\text { delivery delay }\end{array}$ & 4 & $\begin{array}{l}\text { Failure in program } \\
\text { monitoring }\end{array}$ & Effective control & 1 & $\begin{array}{l}\text { Efficient } \\
\text { detection }\end{array}$ & 1 & 4 & 1 \\
\hline 3 & Estimate was not approved & $\begin{array}{l}\text { Equipment } \\
\text { delivery delay }\end{array}$ & 4 & $\begin{array}{l}\text { Failure in program } \\
\text { monitoring }\end{array}$ & Effective control & 1 & $\begin{array}{l}\text { Efficient } \\
\text { detection }\end{array}$ & 1 & 4 & 1 \\
\hline 4 & $\begin{array}{l}\text { Increase in time of } \\
\text { equipment operation }\end{array}$ & Increase in TST & 3 & Device specification & $\begin{array}{l}\text { Little effective } \\
\text { prevention }\end{array}$ & 4 & $\begin{array}{l}\text { Efficient } \\
\text { detection }\end{array}$ & 1 & 12 & 2 \\
\hline 5 & $\begin{array}{l}\text { Increase in time of } \\
\text { equipment operation }\end{array}$ & $\begin{array}{l}\text { Insufficient } \\
\text { equipment }\end{array}$ & 3 & Device specification & $\begin{array}{c}\text { Suitable } \\
\text { prevention }\end{array}$ & 2 & $\begin{array}{l}\text { Detection in } \\
75 \% \text { of the cases }\end{array}$ & 2 & 12 & 2 \\
\hline 6 & $\begin{array}{l}\text { Increase in time of } \\
\text { equipment operation }\end{array}$ & $\begin{array}{l}\text { Clients' } \\
\text { complaint }\end{array}$ & 4 & Device specification & $\begin{array}{l}\text { Suitable } \\
\text { prevention }\end{array}$ & 2 & $\begin{array}{l}\text { Efficient } \\
\text { detection }\end{array}$ & 1 & 4 & 3 \\
\hline
\end{tabular}

FMEA: failure mode and effect analysis; RPN: risk priority number; TST: total service time.

The application of PDSA cycle in association with process description, study of each stage and their interactions, events that resulted in agreement with the experience of other investigators, facilitated the development of these activities ${ }^{(8,16-18,25,27,29)}$.

FMEA assessment resulted in actions to address the root causes, determining the following situations:

- risk reduction through the development of a preventive action plan to promote process improvement;

- immediate removal of the risk source when the pieces of equipment were increased;

- change in the probability of certain risks when the selection process for new employees was initiated;

- sharing the risk with other staff members when the clinical emergency staff was involved in the potential problem.

FMEA contributed to quality planning, allowing the evaluation of interconnected activities designed to generate products and assisting in the identification of controls.

By the end of the project, we observed a paradigm shift and the consolidation of a failure prevention culture, which is corroborated by several authors ${ }^{(22,27)}$.

Its use was well received in the laboratory because it was based on a structured, positive and complete view of the process, anticipating adverse events by means of planning and implementation of preventive actions ${ }^{(10)}$. FMEA was used as a proactive tool for managing risk ${ }^{(4,12)}$.

\section{CONCLUSION}

Laboratories that ensure their quality perform standardized tasks, monitor, improve their performance, create a culture of transparency, define responsibilities and optimize patient safety levels.

FMEA was used to avoid errors, improve the quality and safety of the process, identifying potential failures, and enable the learning of the participants for the development and prioritization of improvement strategies. This new competence provided a rational basis for innovations, increasing the group's ability to promote the necessary changes, insofar as it contains the collective knowledge of laboratory specialists coupled with their expertise and skill, becoming an instrument of education within the laboratory.

Its use facilitated the management of systematic errors because it involved complex configuration processes. Moreover, it had a multidisciplinary approach, which supported decisions. This instrument established itself as valid for proactive laboratory analysis, allowing a thorough assessment of vulnerability (failure modes) and preventing the occurrence of adverse events. Therefore, FMEA became an invaluable tool for identifying the multifactorial nature of most errors. 


\section{RESUMO}

Introdução: 0 artigo apresenta a ferramenta de análise do modo e do efeito de falhas (FMEA) dentro de um laboratório clínico por meio da introdução de nova tecnologia para gasometria e cálcio iônico sérico em analisadores multiparâmetros do tipo testes laboratoriais remotos (TLR) ou point of care testing (POCT). Objetivo: Apresentar a FMEA como ferramenta de gestão de riscos e de melhoria em um laboratório público ao introduzir novas tecnologias. Métodos: A mudança de analisadores de gases multiparâmetros do tipo POCT foi definida e descrita como um processo. A seguir, foram apresentados os critérios para a avaliação dos riscos e a sua quantificação. Foram estudados os modos de falha pelos quais algo poderia falhar nos componentes desse processo. Estabeleceram-se três planos de ações que envolviam melhorias a serem introduzidas na mudança de tecnologia. A FMEA foi aplicada em dois momentos: no início do projeto e após a implantação das medidas propostas. Resultados: O primeiro plano envolveu medidas administrativas vinculadas ao processo licitatório; a segunda ação preventiva envolveu a possibilidade de qual fornecedor venceria a licitação, estudando-se a eficiência do analisador e seu impacto na produtividade; o terceiro conjunto de ações foi dirigido às melhorias no relacionamento com o corpo clínico para minimizar as eventuais reclamações. As últimas ações referiram-se à contratação de novos funcionários para atender à demanda crescente. Conclusão: A FMEA revelou-se um instrumento de melhoria de desempenho para o laboratório, que de maneira proativa identifica, prioriza e mitiga os riscos do paciente.

Unitermos: laboratório clínico; gestão de riscos; análise de riscos; FMEA; segurança do paciente; gasometria.

\section{REFERENCES}

1. ABNT, A. B. D. N. T. Laboratório clínico. Redução do erro através da gestão de riscos e melhoria contínua (ISO/TS 22367:2008, IDT). 2009. Disponível em: <http://www.livreiroonline.com/livros/335179/abntassociacao-brasileira-de-normas-tecnicas/laboratorio-clinico-reducaodo-erro-atraves-da-gesta0-de-riscos-e-melhoria-continua-isots-223672. html >. Acesso em: 3 dez. 2012.

2. ADACHI, W.; LODOLCE, A. E. Use of failure mode and effects analysis in improving the safety of i.v. drug administration. Am J Health Syst Pharm, v. 62 , n. 9, p. 917-20, 2005.

3. APKON, M. et al. Design of a safer approach to intravenous drug infusions: failure mode effects analysis. Qual Saf Health Care, v. 13, n. 4, p. 265-71, 2004.

4. BAGIAN, J. P. Healthcare Failure Mode and Effect Analysis - HFMEA. Washington, 2009. Disponível em: <http:/www.patientsafety.gov/ CogAids/HFMEA/index.html\#page=page-1>. Acesso em: 3 dez. 2012.

5. BATES, D. W. Improving safety with information technology. $N$ Engl J Med, v. 348, n. 25, p. 2526-34, 2003.

6. BERWICK, D. M. Continuous improvement as an ideal in health care. N Engl J Med, v. 320, n. 1, p. 53-6, 1989.

7. BONINI, P. et al. Errors in laboratory medicine. Clin Chem, v. 48, n. 5 , p. 691-8, 2002.

8. BUHR, G. T.; WHITE, H. K. Quality improvement initiative for chronic pain assessment and management in the nursing home: a pilot study. JAm Med Dir Assoc, v. 7, n. 4, p. 246-53, 2006.

9. BURGMEIER, J. Failure mode and effect analysis: an application in reducing risk in blood transfusion. Jt Comm J Qual Improv, v. 28, n. 6, p. 331-9, 2002.
10. CAPUNZO, M. et al. A FMEA clinical laboratory case study: how to make problems and improvements measurable. Clin Leadersh Manag Rev, v. 18, n. 1, p. 37-41, 2004.

11. CARRAR0, P.; PLEBANI, M. Process control reduces the laboratory turnaround time. Clin Chem Lab Med, v. 40, n. 4, p. 421-2, 2002.

12. DEROSIER, J. et al. Using health care failure mode and effect analysis: the VA national center for patient safety's prospective risk analysis system. Jt Comm J Qual Improv, v. 28, n. 5, p. 248-67, 2002.

13. DINTZIS, S. M. et al. Communicating pathology and laboratory errors: anatomic pathologists and laboratory medical directors attitudes and experiences. Am J Clin Pathol, v. 135, p. 760-5, 2011.

14. DINTZIS, S. M.; GALLAGHER, T. H. Disclosing harmful pathology errors to patients. Am J Clin Pathol, v. 31, n. 4, p. 465-5, 2009.

15. DONABEDIAN, A. Explorations in quality assessment and monitoring. Ann Arbor, MI: Health Administration Press, 1980. ISBN 0914904477, 0914904485. Disponível em: <http://openlibrary.org/books/ OL4100737M/Explorations_in_quality_assessment_and_monitoring > Acesso em: 8 dez. 2013.

16. ERDEK, M. A.; PRONOVOST, P. J. Improving assessment and treatment of pain in the critically ill. Int J Qual Health Care, v. 16, p. 59-64, 2004.

17. ESMAIL, R. et al. Using healthcare failure mode and effect analysis tool to review the process of ordering and administrating potassium chloride and potassium phosphate. Healthc Q, v. 8, Spec No, p. 73-80, 2005.

18. LEAPE, L. L. et al. Developing and implementing new safe practices: voluntary adoption through statewide collaboratives. Qual Saf Health Care, v. 15, n. 4, p. 289-95, 2006.

19. LINDA, T.; KOHN, J. M. C.; MOLLA, S.; DONALDSON, M. S. To err is human: building a safer health system. Committee on Quality of Health Care in America, Institute of Medicine, 2000. 312 ISBN 
978-0-309-06837-6. Disponível em: <http://www.nap.edu/openbook. php?isbn=0309068371\&page=1 > . Acesso em: 8 dez. 2012.

20. MIL-STD-1629A: procedures for performing a failure mode, effects and criticality analysis. 2006. ISSN 1154228017. Disponível em: <http:// www.eehomepage.com/refs.php?Specific $=1154228017>$. Acesso em: 9 dez. 2012

21. NAKHLEH, R. E. Disclosure of errors in pathology and laboratory medicine. Am J Clin Pathol, v. 135, p. 666-7, 2011.

22. PAPASTRAT, K.; WALLACE, S. Teaching baccalaureate nursing students to prevent medication errors using a problem-based learning approach. J Nurs Educ, v. 42, n. 10, p. 459-64, 2005.

23. PLEBANI, M.; CARRARO, P. Mistakes in a stat laboratory: types and frequency. Clin Chem, v. 43, n. 8, Pt. 1, p. 1348-51, 1997.

24. SAWANT, A.; DIETERICH, S.; SVATOS, M.; KEALL, P. Failure mode and effect analysis-based quality assurance for dynamic MLC tracking systems. Medical Physics. 2012. Disponível em: <http://online. medphys.org/resource/1/mphya6/v37/i12/p6466_s1>. Acesso em: 9 dez. 2012
25. SMITH, D. S.; HAIG, K. Reduction of adverse drug events and medication errors in a community hospital setting. Nurs Clin North Am, v. 40, p. 25-32, 2005

26. SPATH, P. Get more out of your FMEAs. Hosp Peer Rev, v. 29, n. 1, p. 13-6, 2004.

27. VAN TIEL, F. H. et al. Plan-do-study-act cycles as an instrument for improvement of compliance with infection control measures in care of patients after cardiothoracic surgery.J Hosp Infect, v. 62, p. 64-70, 2006.

28. VAN TILBURG, C. M. et al. Health care failure mode and effect analysis: a useful proactive risk analysis in a pediatric oncology ward. Qual Saf Health Care, v. 15, p. 58-63, 2006.

29. WARBURTON, R. N. et al. Identification of seniors at risk: process evaluation of a screening and referral program for patients aged $>$ or $=75$ in a community hospital emergency department. Int J Health Care Qual Assur Inc Leadersh Health Serv, v. 17, n. 6, p. 339-48, 2004.

30. WOODHOUSE, S.; BURNEY, B.; COSTE, K. To err is human: improving patient safety through failure mode and effect analysis. Clin Leadersh Manag Rev, v. 18, n. 1, p. 32-6, 2004.

\section{MAILING ADDRESS}

\section{Maria Elizabete Mendes}

Divisão de Laboratório Central do HCFMUSP; Núcleo da Qualidade e Sustentabilidade; Av. Dr. Enéas de Carvalho Aguiar, 155; Prédio dos Ambulatórios, $2^{\circ}$ andar, bloco 09; Cerqueira César; CEP: 05403-000; São Paulo-SP, Brazil; e-mail: m.mendes@hc.fm.usp.br. 